\title{
EVALUASI LIMA JENIS INNER CARRIER DAN FORMULASI BACILLUS SUBTILIS UNTUK PENGENDALIAN HAWAR PELEPAH JAGUNG (RHIZOCTONIA SOLANI KUHN)
}

\author{
Amran Muis, Nurasiah Djaenuddin, \& Nurnina Nonci \\ Balai Penelitian Tanaman Serealia \\ J1. Dr. Ratulangi No. 274, Maros 90514 \\ E-mail: amranmuis1@gmail.com
}

\begin{abstract}
Evaluation of five inner carriers and Bacillus subtilis formulation to control banded leaf and sheath blight (Rhizoctonia solani Kuhn). One alternative control method against plant pathogens is the use of antagonistic microorganisms, such as Bacillus subtilis. The use of the antagonistic bacteria on corn especially in Indonesia is still lack. The objective of this research was to evaluate some inner carrier and to make formulated antagonistic B. subtilis to be used as biological control agents on corn diseases. This research consists of laboratory and greenhouse activities. The laboratory activities consist of B. subtilis biomass production, formulation of B. subtilis, and evaluation of five types of inner carrier. In the greenhouse, testing the formulation $B$. subtilis with talc as an inner carrier, which is compared with the treatment solution of $B$. subtilis, nordox, metalaxyl fungicides. The data collected in this study were percentage of germination, damping off due to pathogen $R$. solani, plant height, plant fresh weight, and percentages of $R$. solani incidence on 14 DAP. The results showed that talc powder and corn flour were the best inner carrier to be used in sorage formulation of antagonistic Bacillus. Formulated Bacillus subtilis TM4 showed no negative affect on seed germination and able to suppress the development of $R$. solani in greenhouse.
\end{abstract}

Key words: Bacillus subtilis, formulation, inner carrier, Rhizoctonia solani

\begin{abstract}
ABSTRAK
Evaluasi lima jenis inner carrier dan formulasi Bacillus subtilis untuk pengendalian hawar pelepah jagung (Rhizoctonia solani Kuhn). Salah satu alternatif pengendalian patogen tanaman yaitu pemanfaatan mikroorganisme antagonis seperti Bacillus subtilis. Penggunaan bakteri antagonis tersebut pada tanaman jagung di Indonesia masih sangat kurang. Penelitian ini bertujuan mengevaluasi beberapa inner carrier dan membuat formulasi bakteri antagonis B. subtilis untuk digunakan sebagai agensia pengendali hayati penyakit pada tanaman jagung. Kegiatan penelitian ini terdiri dari kegiatan laboratorium dan rumah kaca. Di laboratorium dilakukan produksi biomass $B$. subtilis, pembuatan formulasi B. subtilis, dan evaluasi formulasi dari lima jenis inner carrier. Di rumah kaca, dilakukan pengujian formulasi $B$. subtilis dengan talc sebagai inner carrier yang dibandingkan dengan perlakuan larutan $B$. subtilis, fungisida nordox, dan fungisida metalaxyl. Pengamatan dilakukan terhadap daya kecambah, damping off akibat patogen $R$. solani, tinggi tanaman, berat segar tanaman, dan persentase serangan $R$. solani pada 14 HST. Hasil penelitian menunjukkan bahwa talc dan tepung jagung merupakan inner carrier yang terbaik untuk digunakan dalam pembuatan formulasi bakteri antagonis B. subtilis. Formulasi B. subtilis TM4 tidak berpengaruh negatif terhadap daya kecambah benih serta mampu menekan perkembangan $R$. solani di rumah kaca.
\end{abstract}

Kata kunci: Bacillus subtilis, formulasi, inner carrier, Rhizoctonia solani

\section{PENDAHULUAN}

Semua bagian dari tanaman jagung adalah rentan terhadap serangan berbagai jenis penyakit yang dapat menurunkan baik kualitas maupun kuantitas. Selain penyakit bulai, sejumlah penyakit penting pada tanaman jagung seringkali berpengaruh secara ekonomi, diantaranya adalah penyakit hawar pelepah yang disebabkan oleh cendawan Rhizoctonia solani dan penyakit bercak daun yang disebabkan oleh cendawan Bipolaris maydis.

Cendawan $R$. solani adalah patogen tular tanah dan memiliki kisaran inang yang luas, sehingga sulit dikendalikan (Ogoshi, 1987). Pengendalian terhadap penyakit tersebut selama ini masih mengandalkan pada penggunaan pestisida kimiawi, sedangkan penggunaan varietas tahan masih sangat terbatas jumlahnya. 
Beberapa tahun belakangan ini, penelitian tentang pemanfaatan mikroorganisme antagonis untuk mengendalikan penyakit-penyakit tersebut banyak dilakukan. Salah satu mikroorganisme antagonis yang menunjukkan hasil yang baik dalam pengendalian patogen penyebab penyakit adalah bakteri antagonis Bacillus subtilis yang keefektifannya dalam mengendalikan penyakit-penyakit pada berbagai komoditas telah banyak menunjukkan hasil yang baik (Kilian et al., 2000; Schisler et al., 2002; EPA, 2003). Agensia pengendali hayati menunjukkan kemampuannya dalam menghambat perkembangan penyakit tanaman serta meningkatkan pertumbuhan tanaman dengan mekanisme yang khas (Keel \& Defago, 1997). Rustam et al. (2011) telah memperoleh beberapa bakteri antagonis yang potensial sebagai agensia pengendali hayati penyakit hawar pelepah padi. Namun penggunaan bakteri antagonis sebagai agensia hayati tersebut pada tanaman jagung masih sangat kurang terutama di Indonesia.

Untuk memudahkan aplikasi bakteri antagonis untuk mengendalikan penyakit tanaman, dibutuhkan suatu formulasi dengan bahan inner carrier yang tepat sebagai sumber karbon. Berdasarkan hal tersebut di atas penelitian ini dilakukan untuk mengevaluasi beberapa inner carrier untuk digunakan dalam pembuatan formulasi bakteri antagonis Bacillus.

\section{METODE PENELITIAN}

Tempat dan Waktu. Penelitian ini dilaksanakan di Laboratorium Penyakit Tanaman dan rumah kaca Balai Penelitian Tanaman Serealia (Balitsereal) di Maros Sulawesi Selatan, pada bulan Februari sampai dengan Mei 2013.

Produksi Biomass B. subtilis. Isolat B. subtilis (3 isolat terbaik dari penelitian sebelumnya) diperbanyak pada media Potato Dextrose Broth (PDB) (250 g kentang $+20 \mathrm{~g}$ dextrose $+1000 \mathrm{ml}$ akuades steril). Sebanyak $180 \mathrm{ml}$ larutan PDB tersebut dimasukkan ke dalam Erlenmeyer berukuran $1000 \mathrm{ml}$ yang diulang 5 kali, kemudian disterilkan pada tekanan 15 psi selama 15 menit. Setelah sterilisasi, setiap erlenmeyer diinokulasi dengan B. subtilis yang berumur 36 jam dan terlebih dahulu dilarutkan ke dalam akuades steril. Kultur tersebut kemudian dikocok selama $36 \mathrm{jam}$. Biomass yang dihasilkan dipanen dengan menggunakan alat sentrifugasi pada kecepatan $5000 \mathrm{rpm}$ selama 6 menit. Sel bakteri hasil sentrifugasi inilah yang digunakan di dalam formulasi.
Evaluasi beberapa Inner carrier sebagai Bahan Formulasi B. subtilis. Inner carrier yang akan dievaluasi dan bahan additive yang akan digunakan dalam formulasi adalah:

A. Talc $+0,25 \%$ yeast extract $+1 \% \mathrm{CMC}$

B. Tepung beras $+0,25 \%$ yeast extract $+1 \% \mathrm{CMC}$

C. Tepung tapioka $+0,25 \%$ yeast extract $+1 \% \mathrm{CMC}$ D. Tepung jagung $+0,25 \%$ yeast extract $+1 \%$ CMC

E. Tepung beras pecah $+0,25$ yeast extract $+1 \% \mathrm{CMC}$

Dua puluh lima g inner carrier, $0,25 \%$ yeast extract, dan 1\% Carboxymethyl Cellulose (CMC) dicampur di dalam wadah aluminium steril. Bahan campuran tersebut lalu dimasukkan ke dalam erlenmeyer berukuran $500 \mathrm{ml}$, kemudian disterilkan pada tekanan 15 psi selama 30 menit. Setelah disterilkan dan didinginkan, dimasukkan $20 \mathrm{ml}$ sel bakteri yang telah disiapkan sebelumnya ke dalam masing-masing campuran inner carrier tadi, kemudian dicampurkan secara merata dan dikeringanginkan di dalam laminar flow selama 48 jam. Setelah kering, bahan formulasi tersebut dimasukkan ke dalam kantong plastik steril kemudian disimpan di dalam suhu ruangan untuk digunakan selanjutnya.

Bahan inner carrier yang paling baik adalah yang mengandung sel bakteri paling banyak. Untuk mengetahui kandungan sel bakteri pada setiap bahan inner carrier, dilakukan pengujian sebagai berikut: satu $\mathrm{g}$ formulasi bakteri dimasukkan ke dalam kantong plastik steril yang berisi $100 \mathrm{~g}$ biji jagung dan telah ditambahkan $1 \mathrm{ml}$ akuades steril, lalu dikocok hingga formulasi tersebut membungkus biji jagung secara merata. Kemudian diambil tiga biji jagung tadi secara acak lalu dimasukkan ke dalam tabung reaksi yang berisi $10 \mathrm{ml}$ akuades steril, lalu diencerkan hingga $10^{-2}$. Dari larutan yang telah diencerkan tadi, diambil 0,1 ml menggunakan pipet steril dan diletakkan pada cawan Petri berisi Potato dextrose peptone agar (PDPA) dengan komposisi $200 \mathrm{~g}$ kentang, $20 \mathrm{~g}$ dekstrose, $20 \mathrm{~g}$ agar, $15 \mathrm{~g}$ peptone dan $1000 \mathrm{ml}$ akuades, lalu disebar dengan menggunakan glass rod hockey. Cawan Petri tersebut kemudian diberi selotip dan diinkubasi dengan posisi terbalik. Setelah 24 jam, koloni bakteri yang terbentuk pada setiap cawan Petri dihitung.

Pengujian Formulasi $B$. subtilis TM4 terhadap Rhizoctonia solani di Rumah Kaca. Sebelum dilakukan pengujian terlebih dahulu disiapkan formulasi B. subtilis TM4 dengan mencampurkan $20 \mathrm{ml}$ suspensi bakteri yang diambil dari kultur bakteri + talc yang sudah disterilkan $+0,25 \%$ yeast extract dan $1 \%$ CMC lalu 
dikeringanginkan di dalam laminar flow chamber selama dua hari.

Inokulum patogen $R$. solani disiapkan dengan membiakkannya pada media campuran beras dan sekam padi yang dimasukkan di dalam plastik berukuran $1 \mathrm{~L}$. Sebelum dibiakkan, media tersebut disterilkan selama 2 jam pada tekanan 15 psi. Setelah sterilisasi diambil potongan biakan $R$. solani dari cawan Petri $\left(3 \mathrm{~mm}^{2}\right)$ lalu dimasukkan ke dalam media steril tadi. Biakan tersebut disimpan di dalam suhu kamar selama 2 minggu. Setelah biakan $R$. solani siap, inokulum tersebut kemudian dicampurkan ke dalam baki plastik yang telah diisi tanah steril dan dibiarkan selama 14 hari. Sebagai kontrol, digunakan tanah pada baki plastik yang tidak diinokulasi dengan $R$. solani. Setelah inokulum siap di dalam baki tadi, ke dalam baki-baki tersebut ditanam biji jagung yang telah diberi perlakuan benih dengan cara $10 \mathrm{~g}$ formulasi bakteri dicampurkan dengan $1 \mathrm{~kg}$ benih jagung di dalam kantong plastik dan dikocok hingga rata. Perlakuan disusun dalam rancangan acak lengkap yang terdiri dari 7 perlakuan dan 3 ulangan sebagai berikut:

$\mathrm{P} 1$ = Seed treatment dengan larutan B. subtilis $\mathrm{TM} 4$

$\mathrm{P} 2=$ Seed treatment dengan formulasi $B$. subtilis TM4+ 0,5\% gum Arabic

P3 = Seed treatment dengan fungisida nordox

$\mathrm{P} 4$ = Seed treatment dengan fungisida metalaxyl

P5 = Seed treatment dengan fungisida nordox + metalaxyl

P6 = Kontrol (diinokulasi dengan $R$. solani)

$\mathrm{P} 7$ = Kontrol (tanpa inokulasi dengan $R$. solani)

Pengamatan dilakukan terhadap daya kecambah pada 7 Hari Setelah Tanam (HST), tinggi tanaman, damping off, berat segar keseluruhan tanaman dan persentase serangan $R$. solani pada 14 HST. Persentase serangan $R$. solani dihitung dengan menggunakan rumus sebagai berikut:

$$
\mathrm{P}=\frac{\mathrm{a}}{\mathrm{b}} \times 100 \%
$$

dengan:

$\mathrm{P}=$ Persentase serangan $R$. solani

$\mathrm{a}=$ Jumlah tanaman terserang $R$. solani

$\mathrm{b}=$ Jumlah tanaman yang diamati

Analisis Data. Data hasil lima jenis inner carrier in vitro dan hasil pengujian in vivo di rumah kaca dianalisis dengan program komputer SAS ver. 9.1.3 (SAS Institute Inc., 2006).

\section{HASIL DAN PEMBAHASAN}

Hasil pengamatan terhadap jumlah koloni bakteri antagonis pada lima inner carrier menunjukkan bahwa talc adalah inner carrier terbaik diantara inner carrier lainnya yang diuji diikuti dengan tepung jagung (Tabel 1). Hal ini diduga karena ukuran partikel dari talc paling kecil diantara inner carrier lain, ini ditandai dengan serbuk talc lebih halus dari inner carrier lain dan sifatnya mudah menyebar sehingga jika disebarkan dalam air terbentuk suspensi yang kental dan akan mudah berikatan dengan larutan bakteri. Menurut Anonim (2014), talc merupakan garam anhidrat yang bersifat cepat terhidrasi dengan mengikat air atau senyawasenyawa yang dapat mengikat air melalui pengikatan di permukaan (surface adhesion) tanpa menjadi basah dan menggumpal.

Pada Tabel 1 tampak bahwa dari tiga isolat $B$. subtilis yang diuji, isolat TM4 menunjukkan populasi bakteri yang terbanyak yakni rata-rata $99 \times 10^{5} \mathrm{cfu} / \mathrm{ml}$. Selain talc, tepung jagung juga memperlihatkan hasil yang baik sebagai inner carrier, terutama bagi isolat BNT5. Pada Tabel 1 nampak bahwa jumlah koloni bakteri antagonis dengan formulasi tepung jagung

Tabel 1. Jumlah koloni 3 isolat B. subtilis pada 5 formulasi di laboratorium

\begin{tabular}{lccc}
\hline \multirow{2}{*}{ Inner carrier } & \multicolumn{3}{c}{ Jumlah koloni B. subtilis (x 105 cfu/ml) } \\
\cline { 2 - 4 } & Isolat TLB1 (57) & Isolat TM4 (87) & Isolat BNt5 (109) \\
\hline Talc & $73,33 \mathrm{a}$ & $99,00 \mathrm{a}$ & $96,67 \mathrm{a}$ \\
Tepung jagung & $29,00 \mathrm{~b}$ & $32,33 \mathrm{~b}$ & $88,00 \mathrm{a}$ \\
Tepung beras pecah & $13,00 \mathrm{c}$ & $9,67 \mathrm{c}$ & $24,33 \mathrm{~b}$ \\
Tepung beras & $11,33 \mathrm{c}$ & $13,00 \mathrm{c}$ & $12,33 \mathrm{~b}$ \\
Tepung tapioka & $5,67 \mathrm{c}$ & $4,33 \mathrm{c}$ & $15,33 \mathrm{~b}$ \\
\hline \multicolumn{1}{c}{ KK $(\%)$} & 29,22 & 15,09 & 13,79 \\
\hline
\end{tabular}

Angka dalam kolom yang diikuti oleh huruf yang sama tidak berbeda nyata menurut uji BNT 5\%. 
sebagai inner carrier adalah sebanyak $88 \times 10^{5} \mathrm{cful}$ $\mathrm{ml}$. Secara statistika, hasil ini tidak berbeda nyata dengan inner carrier talc, namun berbeda nyata dengan inner carrier lainnya. Hal ini menunjukkan bahwa tepung jagung bisa juga digunakan sebagai inner carrier dalam formulasi bakteri antagonis.
Hasil pengujian secara in vivo di rumah kaca disajikan pada Tabel 2 dan Tabel 3. Hasil pengamatan terhadap persentase tanaman tumbuh pada semua perlakuan menunjukkan bahwa persentase benih tumbuh berkisar antara 98,7-99,3\% (Gambar 1). Hasil analisis statistika terhadap rata-rata persentase tanaman tumbuh

Tabel 2. Rata-rata persentase tanaman tumbuh pada 1 MST. RK Balitsereal 2013

\begin{tabular}{|c|c|c|}
\hline No. & Perlakuan & Tanaman tumbuh $(\%)$ \\
\hline 1. & Seed treatment dengan larutan Bacillus & 98,7 \\
\hline 2. & Seed treatment dengan formulasi Bacillus $+0,5 \%$ gum Arabic & 99,3 \\
\hline 3. & Seed treatment dengan fungisida nordox & 99,3 \\
\hline 4. & Seed treatment dengan fungisida metalaxyl & 98,7 \\
\hline 5. & Seed treatment dengan nordox + metalaxyl & 99,3 \\
\hline 6. & Kontrol (diinokulasi) & 98,7 \\
\hline 7. & Kontrol (tanpa inokulasi) & 98,7 \\
\hline \multicolumn{2}{|r|}{$\mathrm{KK}(\%)$} & $1,76 \mathrm{tn}$ \\
\hline
\end{tabular}

Tabel 3. Rata-rata tinggi tanaman, rata-rata berat segar tanaman, dan persentase serangan $R$. solani (14 HST) pada 5 perlakuan dan 2 kontrol di rumah kawat Balitsereal 2013

\begin{tabular}{llccc}
\hline No. & \multicolumn{1}{c}{ Perlakuan } & $\begin{array}{c}\text { Tinggi } \\
\text { tanaman } \\
(\mathrm{cm})\end{array}$ & $\begin{array}{c}\text { Berat segar } \\
\text { tanaman } \\
(\mathrm{g})\end{array}$ & $\begin{array}{c}\text { Persentase } \\
\text { serangan } \\
\text { R. solani }(\%)\end{array}$ \\
\hline 1. & $\quad$ Seed treatment dengan larutan Bacillus & 33,8 & 30,0 & $3,4 \mathrm{~b}$ \\
2. & Seed treatment dengan formulasi Bacillus $+0,5 \%$ gum Arabic & 33,8 & 31,8 & $2,7 \mathrm{ab}$ \\
3. & Seed treatment dengan fungisida nordox & 34,6 & 26,5 & $5,4 \mathrm{bc}$ \\
4. & Seed treatment dengan fungisida metalaxyl & 30,1 & 26,0 & $7,4 \mathrm{c}$ \\
5. & Seed treatment dengan nordox + metalaxyl & 33,7 & 26,6 & $8,1 \mathrm{c}$ \\
6. & Kontrol (diinokulasi) & 32,6 & 27,0 & $18,9 \mathrm{~d}$ \\
7. & Kontrol (tanpa inokulasi) & 33,7 & 27,0 & $0,0 \mathrm{a}$ \\
\hline \multicolumn{1}{c}{ KK $(\%)$} & $10,7 \mathrm{tn}$ & $7,2 \mathrm{tn}$ & $27,8^{*}$ \\
\hline
\end{tabular}

Angka dalam kolom yang diikuti oleh huruf yang sama tidak berbeda nyata menurut uji BNT 5\%.

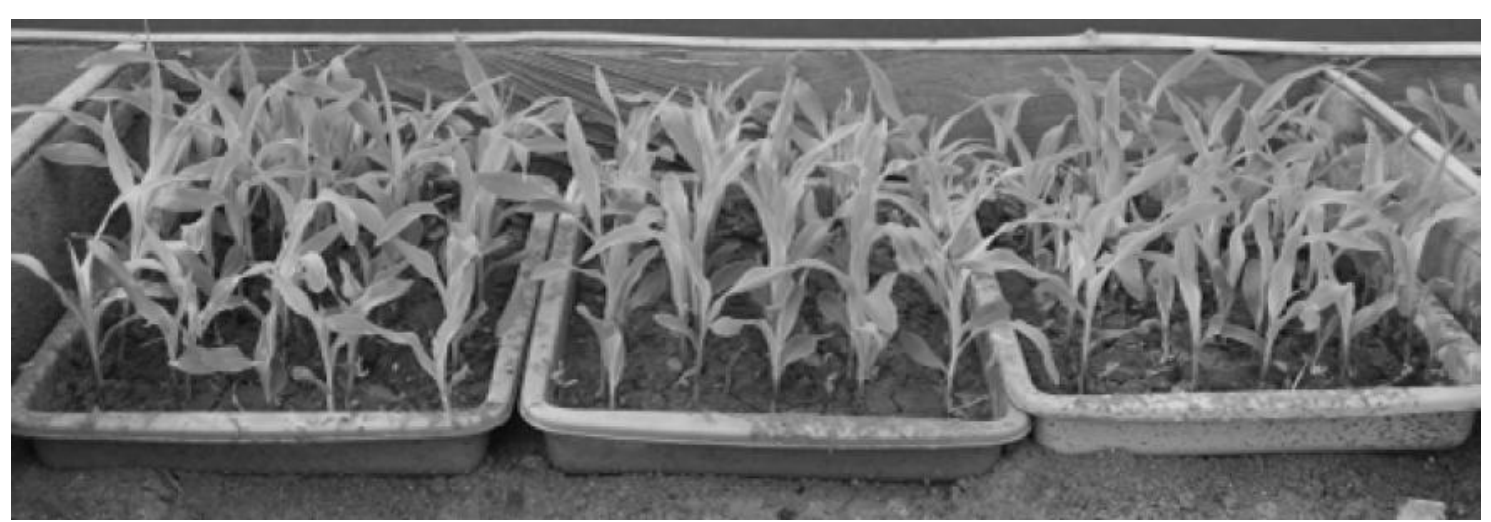

Gambar 1. Keadaan tanaman pada 7 hari setelah tanam di rumah kaca Balitsereal 2013 
pada 1 minggu setelah tanam (MST) menunjukkan tidak ada perbedaan yang nyata antar perlakuan. Hal ini menunjukkan bahwa seed treatment dengan formulasi bakteri antagonis B. subtilis TM4 + yeast extract + $\mathrm{CMC}+$ gum Arabic tidak berpengaruh negatif terhadap daya kecambah benih. Kilian et al. (2000) melaporkan bahwa kolonisasi akar dan rizosfer dipengaruhi oleh sejumlah faktor termasuk teknik aplikasi. Selanjutnya Canaday \& Ownley (1999) mengemukakan bahwa proporsi populasi $B$. subtilis pada akar tergantung pada jumlah $B$. subtilis yang diaplikasikan.

Hasil pengamatan terhadap tinggi tanaman pada 14 HST menunjukkan bahwa hanya perlakuan P4 yang agak pendek dibanding dengan perlakuan lainnya (Tabel 3). Hasil analisis statistika terhadap rata-rata tinggi tanaman menunjukkan tidak ada perbedaan yang nyata antar perlakuan. Pada Tabel 2 tampak bahwa perlakuan benih dengan $B$. subtilis baik yang tanpa formulasi (P1) maupun dengan formulasi (P2) menunjukkan tinggi tanaman yang hampir sama dengan kontrol tanpa inokulasi $R$. solani.

Hasil pengamatan terhadap berat segar 10 tanaman pada 14 HST disajikan pada Tabel 2. Pada Tabel 2 terlihat bahwa walaupun rata-rata tinggi tanaman pada semua perlakuan hampir sama, namun perlakuan benih dengan formulasi $B$. subtilis menunjukkan ratarata berat segar tanaman yang lebih tinggi dibanding perlakuan lainnya. Hal ini menunjukkan bahwa $B$. subtilis disamping sebagai antagonis bagi cendawan, juga berfungsi sebagai pemacu daya tumbuh tanaman, seperti yang dikemukakan oleh Van Loon et al. (1998), perlakuan benih dengan plant growth promoting rhizobacterium (PGPR) seperti Bacillus spp. meningkatkan persentase kecambah benih, vigor tanaman, pertumbuhan akar, biomas tanaman, dan lainlain. Selanjutnya Prathibha \& Siddalingeshwara (2013) mengemukakan bahwa PGPR seperti B. subtilis efektif meningkatkan kualitas benih seperti daya kecambah, indeks vigor, dan kualitas nutrisi seperti kandungan protein dan karbohidrat.

Mishra et al. (2010) mengemukakan bahwa perlakuan benih dengan $B$. subtilis meningkatkan produksi pada tanaman Pelagronium gravelen. Selanjutnya Mohamed \& Gomaa (2012) melaporkan bahwa benih lobak yang diinokulasi dengan $B$. subtilis sebelum tanam, meningkatkan secara nyata biomas segar dan kering akar dan daun. Selain itu bakteri tersebut juga meningkatkan kandungan fitohormon (IAA dan GA) serta kandungan N, P, K, Ca, dan Mg. Baugh (2014) juga mengemukakan bahwa B. subtilis menghasilkan auksin yang bersifat meningkatkan daya tumbuh tanaman.

Hasil pengamatan terhadap persentase serangan $R$. solani pada 14 HST disajikan pada Tabel 3. Hasil analisis statistika terhadap persentase serangan cendawan $R$. solani menunjukkan bahwa perlakuan Seed treatment dengan formulasi B. subtilis TM4 + $0,5 \%$ gum Arabic berbeda nyata dengan perlakuan Seed treatment dengan fungisida metalaxyl dan seed treatment dengan fungisida nordox + metalaxyl serta dengan perlakuan kontrol (diinokulasi dengan $R$. solani). Perlakuan Seed treatment dengan formulasi B. subtilis TM4 + 0,5\% gum Arabic tersebut tidak berbeda nyata dengan perlakuan seed treatment dengan larutan $B$. subtilis TM4, seed treatment dengan fungisida nordox, dan kontrol (tanpa inokulasi dengan $R$. solani). Namun demikian, persentase serangan cendawan $R$. solani ditemukan terendah pada perlakuan Seed treatment dengan formulasi $B$. subtilis TM4 + 0,5\% gum Arabic dengan persentase serangan $2,7 \%$. Hal ini diduga tanaman memberikan reaksi ketahanannya terhadap infeksi patogen akibat adanya bakteri antagonis yang juga berperan dalam meningkatkan mekanisme ketahanan jaringan tanaman. Menurut Van Loon et al. (1998), mekanisme ketahanan tanaman yang dipengaruhi oleh bakteri antagonis ini dikenal dengan istilah ketahanan terinduksi secara sistemik (induced systemic resistance). Dan persentase serangan tertinggi ditunjukkan oleh perlakuan kontrol (tanpa inokulasi dengan $R$. solani).

Hasil penelitian ini menunjukkan bahwa formulasi bakteri antagonis $B$. subtilis TM4 dapat menekan perkembangan serangan cendawan $R$. solani. Kemampuan ini mungkin disebabkan oleh antibiotik yang dihasilkan oleh bakteri tersebut. Seperti yang dikemukakan oleh Islam et al. (2012), bahwa komposisi nutrisi (karbon dan nitrogen) dan kondisi lingkungan ( $\mathrm{pH}$ dan temperatur) mempengaruhi produksi antibiotik dari bakteri antagonis. EPA (2003) melaporkan bahwa $B$. subtilis strain QST 713 dapat mencegah perkembangan sejumlah jenis cendawan tertentu yang kemungkinan dengan cara bersaing dalam hal kebutuhan hara, lingkungan pertumbuhan tanaman, dan secara langsung mengkolonisasi cendawan patogen. Niu et al. (2011) melaporkan bahwa Bacillus cereus AR156 merupakan PGPR yang menginduksi ketahanan tanaman terhadap berbagai jenis patogen termasuk Pseudomonas syringae pv. tomato DC3000. Bakteri ini meningkatkan biomas tanaman dan menekan perkembangan penyakit di daun. 


\section{SIMPULAN}

Talc dan tepung jagung merupakan inner carrier yang terbaik untuk digunakan dalam pembuatan formulasi bakteri antagonis Bacillus subtilis. Formulasi bakteri antagonis Bacillus subtilis TM4 tidak berpengaruh negatif terhadap daya kecambah benih. Formulasi bakteri antagonis Bacillus isolat TM4 mampu menekan perkembangan cendawan patogen $R$. solani di rumah kaca.

\section{DAFTAR PUSTAKA}

Anonim. 2014. Bahan Tambahan Pangan. Buku Putih Kementerian Kesehatan Republik Indonesia, Jakarta.

Baugh B. 2014. Bacillus subtilis Plant Growth Promoter. http:/living-soils.com/bacillus-subtilisplant-growth-promoter/. Diakses 3 April 2014.

Canaday CH \& Ownley BH. 1999. Effects of Seed Treatment Chemicals and Bacillus subtilis on Snap Bean Seedling Diseases, Growth, and Yield. The University of Tennessee, Knoxville.

EPA (U.S. Environmental Protection Agency). 2003. Bacillus subtilis QST713 (006479). http:// www.epa.gov. Diakses 9 Mei 2005.

Islam MdR, Jeong YT, Lee YS, \& Song CH. 2012. Isolation and identification of antifungal compounds from Bacillus subtilis C9 inhibiting the growth of plant pathogenic fungi. Mycobiology 40(1): 59-66.

Keel C \& Defago G. 1997. Interactions between beneficial soil bacteria and root pathogens: mechanisms and ecological impact. In: Gange AC \& Brown VK (Eds.). $36^{\text {th }}$ Symposium of The British Ecological Society Multitrophic Interaction in terrestrial system. pp. 27-47. Blackwell Science Oxford.

Kilian M, Steiner U, Krebs B, Junge H, Schmiedeknecht G, \& Hain R. 2000. FZB24® Bacillus subtilis mode of action of a microbial agent enhancing plant vitality. Pflanzenschutz-Nachrichten Bayer 1/00 1: 72-93.
Mishra RK, Prakash Om, Alam M, \& Dikshit A. 2010. Influence of plant growth promoting rhizobacteria (PGPR) on the productivity of Pelargonium graveolens L. Herit. Recent Res. Sci. Technol. 2(5): 53-57.

Mohamed HI \& Gomaa EZ. 2012. Effect of plant growth promoting Bacillus subtilis and Pseudomonas fluorescens on growth and pigment composition of radish plants (Raphanus sativus) under $\mathrm{NaCl}$ stress. Photosynthetica 50(2): 263-272.

Niu DD, Liu HX, Jiang CH, Wang YP, Wang QY, Jin HL, \& Guo JH. 2011. The plant growth-promoting rhizobacterium Bacillus cereus AR156 induces systemic resistance in Arabidopsis thaliana by simultaneously activating salicylate-and jasmonate/ethylene-dependent signaling pathways. Mol. Plant-Microbe Interact. 24(5): 533-542.

Ogoshi A. 1987. Ecology and pathogenicity of anastomosis and intraspecific group of Rhizoctonia solani KÜhn. Annu. Rev. Phytopathol. 25: 125-143.

Prathibha KS \& Siddalingeshwara KG. 2013. Effect of plant growth promoting Bacillus subtilis and Pseudomonas fluorescence as Rhizobacteria on seed quality of sorghum. Int. J. Curr. Microbiol. App. Sci. 2(3): 11-18.

Rustam, Giyanto, Wiyono S, Santosa DA, \& Susanto S. 2011. Seleksi dan identifikasi bakteri antagonis sebagai agens pengendali hayati penyakit hawar pelepah padi. Penelitian Pertanian Tanaman Pangan 30(3): 164-171.

SAS Institute Inc. 2006. Base SAS ® 9.1.3 Procedures Guide. Second Edition. Volumes 1, 2, 3, and 4. Cary.

Schisler DA, Khan NI, Boehm MJ, \& Slininger PJ. 2002. Greenhouse and field evaluation of biological control of Fusarium head blight on durum wheat. Plant Dis. 86(12): 1350-1356.

van Loon LC, Bakker PAHM, \& Pieterse CMJ. 1998. Systemic resistance induced by rhizosphere bacteria. Annu. Rev. Phytopathol. 36: 453-483. 